

\title{
Eye Neoplasm Research: A Bibliometric Analysis from 1966 to 2012
}

Christophe Boudry, Frédéric Mouriaux

\section{To cite this version:}

Christophe Boudry, Frédéric Mouriaux. Eye Neoplasm Research: A Bibliometric Analysis from 1966 to 2012. European Journal of Ophthalmology, 2015, 25 (4), pp.357-365. 10.5301/ejo.5000556 . hal01160475

\section{HAL Id: hal-01160475 \\ https://hal.science/hal-01160475}

Submitted on 7 Dec 2017

HAL is a multi-disciplinary open access archive for the deposit and dissemination of scientific research documents, whether they are published or not. The documents may come from teaching and research institutions in France or abroad, or from public or private research centers.
L'archive ouverte pluridisciplinaire HAL, est destinée au dépôt et à la diffusion de documents scientifiques de niveau recherche, publiés ou non, émanant des établissements d'enseignement et de recherche français ou étrangers, des laboratoires publics ou privés. 


\section{TITLE PAGE}

\section{Title of the article}

Eye Neoplasm Research: A Bibliometric Analysis from 1966 to 2012

\section{Short Title}

Eye Neoplasm Research: A Bibliometric Analysis

\section{Authors}

Christophe Boudry $\mathrm{PhD}^{1}$, Fréderic Mouriaux, $\mathrm{MD}, \mathrm{PhD}^{2}$

\section{Author affiliations}

${ }^{1,2}$ Normandy University, Université de Caen Basse-Normandie, Caen, France

${ }^{1}$ URFIST/Ecole nationale des Chartes, Paris, France and Laboratoire « Dispositifs d'Information et de Communication à l'Ėre Numérique » Conservatoire National des Arts et Métiers, Paris, France

${ }^{2}$ Service d'Ophtalmologie, Caen CHU Côte de Nacre F-14000, France

\section{Corresponding author:}

C. Boudry

Centre de Formation aux Carrières de Bibliothèques (CFCB)

Université de Caen Basse-Normandie

Esplanade de la Paix

CS 14032

France

14032 CAEN Cedex 5 
Tel: (+33) 02.31.56.51.60

Fax: (+33) 02.31.56.58.18

Email: boudry@enc.sorbonne.fr

\section{Conflict of Interest}

"None of the authors has conflict of interest with the submission"

\section{Financial support}

"No financial support was received for this submission" 


\section{ABSTRACT}

Purpose: To calculate the growth rate of biomedical literature on eye neoplasms and to assess which journals, countries, and continents are the most productive.

Methods: PubMed was used to search for papers published from 1966 to 2012. Total number of articles per year was fitted to a linear equation as well as an exponential curve. To identify the core journals and predict the number of journals containing articles related to eye neoplasms, Bradford's law was applied. The mean number of publications per year and per author were calculated. For each country and each continent, the Gross Domestic Product (GDP) index (publications per 1 billion US dollars of GDP) and the population index (publications per million inhabitants) were calculated.

Results: A total of 27943 references were retrieved. The growth in the number of publications showed a linear increase with a yearly average growth rate of $2.08 \%$, which was lower than for the whole PubMed database (3.59\%). Using Bradford's law, 17 core journals were identified among which two journals produced more than 1000 articles (JAMA Ophthalmology and American journal of ophthalmology). Europe was the most productive continent, followed by North America and Asia. The United States was by far the predominant country in number of publications, followed by Germany and the United Kingdom. However, population and GDP indexes showed that absolute production did not reflect the production per capita nor the economic efficiency.

Conclusions: This bibliometric study provides data contributing to a better understanding of the eye neoplasm research field. 
Key words: eye - neoplasms - socioeconomics - publication - journal 


\section{MANUSCRIT TEXT}

\section{INTRODUCTION}

"Eye neoplasms" is a general term used to describe many types of tumors that occur in and around the eye. Eye neoplasms include primary and metastatic tumors of the globe (intra ocular and conjunctiva) and ocular adnexa (orbit, eyelid and lacrimal structures). The treatment of ocular tumors is generally a multi-disciplinary effort requiring coordination between ocular oncologists, medical oncologists, radiation specialists, pediatricians, and internal medicine specialists. There are a number of excellent institutions and departments in the world that specialize in the diagnosis and management of eye cancer. International journals serve as a forum for exchange and are a significant indicator of research activity. Bibliometrics, first introduced by Pritchard in 1969 (1), refers to methods which utilize quantitative analysis and statistics to describe distribution patterns of publications, temporal evolution, and geographical distribution of research in a given field. Bibliometrics is helpful in mapping the literature related to a research field and can provide useful data, leading to a better understanding of scientific fields such as cancer research $(2,3)$ or ophthalmology (4-8). To the best of our knowledge, there are no similar reports examining worldwide contributions to the body of literature related to eye neoplasms.

The objective of the study was to give an overview of eye neoplasm research using the PubMed database over the period of 1966 to 2012. More specifically, we wanted to know which journals, countries, and continents are the most productive. 


\section{MATERIAL AND METHODS}

\section{Bibliographic search}

The Medline database via PubMed developed by the National Center for Biotechnology Information (NCBI) at the National Library of Medicine (NLM) was used for the search for papers in this study. PubMed was used because it was the most widely used database in the field of medicine (9). The search strategy was: "Eye Neoplasms" [Mesh] AND 1966:2012 [DP] AND journal article [PT], where MeSH stands for "Medical Subject Headings", DP "Date of Publication", and PT "Publication Type". The MeSH term "Eye Neoplams", whose definition in the NLM controlled vocabulary thesaurus is "Tumors or cancer of the eye", was chosen because it covers all tumors or cancer of the eye (Fig. 1). "Journal Article [MeSH]" includes the following publication types: journal articles, introductory journal articles, and reviews. The year 1966 was chosen because it corresponds to the beginning of the Medline database. The study was limited to original research articles, corresponding to "Journal article" shown under the "Publication type" field. Data were downloaded from PubMed in Extensible Markup Language (XML) and were processed through developed Hypertext Preprocessor language (PHP) scripts, then were imported to Microsoft Excel 2010 (Microsoft, Redmond, USA) for data processing.

\section{Analysis of growth of literature}

Using Excel software, the total number of articles related to eye neoplasms per year was fitted to a linear equation as well as an exponential curve for our search strategy. The average yearly growth rate (10) of the literature related to eye neoplasms was calculated as the mean percentage of annual growth rate for the period studied using 
the equation: Annual Growth Rate = Current Year Total Number of Articles Previous Year Total Number of Articles/Previous Year Total Number of Articles. The average yearly growth rate was also calculated for the whole PubMed database for the period 1966-2012.

\section{Bradford's law}

Bradford's law has been used extensively in the information science literature to describe the dispersion of articles in any scientific field (11) and to identify "core journals" of serial titles (10). In this way, Bradford's law may predict the total number of journals containing articles on a subject once the number in the core and middle zone of journals is known (12). To identify the core journals and predict the number of journals containing articles dedicated to eye neoplasms, Bradford's law was applied by dividing the publication frequency ranked journals into three groups with each group representing approximately the same number of articles.

\section{Analysis of journals and language of publication}

The 2012 Journal Citation Reports (JCR) (Thomson Reuters, New York, USA) was used for Impact Factor (IF) determination and for the rank of the journal in the JCR in the category "Ophthalmology". Moreover, we divided the entire period (1966-2012) into five periods (1966-1972, 1973-1982, 1983-1992, 1993-2002, 2003-2012) for analyzing the 17 most productive journals during the divided period. Thus, the 1982 , 1992, 2002 Journal Citation Reports (JCR) were also used to assess IF for the same years. Language of publication was determined using the "Language" field for all articles retrieved. The percentage of papers published in English in the entire PubMed database between 1966 and 2012 was also calculated using the following 
search strategy: Medline [sb] OR publisher [sb] OR pubstatusaheadofprint AND 1966:2012 [DP] AND journal article [PT] where sb means "subset".

\section{Analysis of country affiliations}

The country of affiliation of the first author was determined by the address in the "Affiliation" field. When the country was absent in the address, it was determined from the city or email address using an Internet search engine if necessary. If the name of a country no longer existed (eg, Yugoslavia), the city was used to find the name of the existing country in 2012. England, Scotland, Northern Ireland, and Wales were grouped into the United Kingdom. Hong Kong was considered as part of China.

The Gross Domestic Product (GDP) is the market value of all officially recognized final goods and services produced within a country in a given period. GDP per capita is often considered an indicator of a country's standard of living (13). For each country and each continent, the GDP index (publications per 1 billion US dollars of GDP) and the population index (publications per million inhabitants) were calculated using the World Development Indicators from the online databases of the World Bank (13), as done previously (14-16). The GDP and the population index were calculated using the mean GDP and mean number of inhabitants from 1993 to 2012.

\section{RESULTS}

\section{Growth of literature}

The publication search resulted in a total of 27943 references over the period of 1966 to 2012 . The number of articles produced overall has grown from 372 articles per year in 1966 to 756 in 2012. Using the cumulative number of publications for eye 
neoplasms, we calculated the linear adjustment and the exponential adjustment ( $y=$ $591.71 x-1 E+6$ with $r^{2}=0.99$, and $y=2^{-54} e^{0.0667 x}$ with $r^{2}=0.84$, respectively), showing linear growth (Fig. 2). We calculated that the average yearly growth rate was $2.08 \%$ from 1966 to 2012 . For the whole PubMed database the average yearly growth rate was $3.59 \%$.

\section{Journals}

The number of journals that published at least one article related to the eye during the period 1966-2012 was 2 153. According to Bradford's law, the total number of articles compared to the number of journals in order of decreasing productivity was divided into 3 zones containing the same number of articles (Fig. 3 ). The first third of the total number of articles ( $n=9356)$ represents the journals $(n=17 ; 0.8 \%)$ that published the most articles (between 252 and 1260 articles). This first third is presumed to be of the highest interest for researchers interested in eye neoplasms (core journals). The middle third ( $n=9$ 297) corresponds to the journals ( $n=108 ; 5 \%)$ that contained an average number of articles, and the last third ( $n=9$ 290) includes the "long tail" of journals ( $n=2028 ; 94.2 \%$ ) that published few articles (from 1 to 35 ). The last third should be regarded as of less importance for eye neoplasm researchers. As an example, 1155 journals (53.6\%) published only 1 or 2 articles related to eye neoplasms over the 46-year study period. The distribution of journals in the three groups corresponds respectively to ratios equal to $1 ; 6.4$ (108/17), and $119.3(2028 / 17)$. Consequently, according to Braford's'law, the theoretical number of journals was calculated in the three groups using $1, n, n^{2}$ ratios which were $17(n=1)$, $108(n=6.4)$, and $686\left(n^{2}=40.3\right)$, respectively. Thus, the theoretical ratio of number of 
journals and theoretical number of journals (686) in the last third are lower than the real values $(2028)$.

Table IA describes the core journals according to Bradford's law (17 most productive journals for the period 1966-2012). Five journals of 17 did not have any IF. The 12 journals with IF all belong to the category "Ophthalmology" of the JCR. Among the 17 core journals according to Bradford's law, only six were classified in the top ten according to the IF of the category "Ophthalmology". Furthermore, the journal with the highest IF in the category "Ophthalmology" (Progress in retinal and eye research) was not among the 17 most productive journals.

Two journals produced more than 1000 articles (JAMA ophthalmology, formerly Archives of ophthalmology and American journal of ophthalmology) from 1966 to 2012 (Table 1A). Five journals produced more than 20 articles related to eye neoplasms per year of activity (JAMA ophthalmology, American journal of ophthalmology, Opththalmology, Ophthalmic plastic reconstructive surgery, and Bulletin des sociétés d'ophtalmologie de France).

The percentage of articles related to eye neoplasms relative to the total number of articles published by the 17 core journals according to Bradford's law was from 2.6 (Investigative ophthalmology \& visual science) to 24.49 (Ophthalmic plastic and reconstructive surgery). Unexpectedly, JAMA ophthalmology, which was the most productive journal, published only $10.27 \%$ of articles related to eye neoplasms compared to the total number of articles published.

Because some journals were recent, we decided to divide this long period of 47 years into five periods (1966-1972, 1973-1982, 1983-1992, 1993-2002, 2003-2012) (Tab. 10 
IB). Some of the 17 core journals according to Bradford's law for the period 19662012 showed a recent growth in the number of articles published in ocular oncology, especially Ophthalmic plastic reconstructive surgery, Investigative ophtalmology \& visual science, and Retina. Note that only 9 journals among the 17 core journals according to Bradford's law (Table 1A) published articles related to eye neoplasms during the five consecutive periods (Table 1B). Among them, four were always in the top 17 most productive journals during these five consecutive periods (JAMA ophthalmology, American journal of ophthalmology, The British journal of ophthalmology and Klinische Monatsblätter für Augenheilkunde). In order to complete data shown in Table IB, Table IC describes others journals (not belonging to the 17 core journals according to Bradford's law) appearing in the 17 most productive journals for the 5 periods studied: as an example, for the period 2003-2012, five journals not belonging to the 17 core journals according to Bradford's law appear. Of note, two journals that were not ophthalmologic emerge: Cancer for the three first periods and International journal of radiation oncology, biology, physics for the last period.

\section{Languages of publication}

Thirty different languages of publication were identified. The 7 predominant languages were English ( $n=20$ 599; 73.72\%), French ( $n=1948 ; 6.97 \%)$, German ( $n=1$ 929; 6,90\%), Russian ( $n=684 ; 2.45 \%)$, Japanese $(n=579 ; 2.07 \%)$, Polish $(n=545$; $1.95 \%)$, and Chinese ( $n=423 ; 1.51 \%)$. All other languages amounted to less than $1 \%$. The percentage of articles in English in the entire Pubmed database for the same period was $82.3 \%$.

\section{Geographical distribution of authors (country contributions)}


The study of the affiliation of the first author allowed us to identify 16005 country affiliations for the 27943 articles (57.27\%). Because Medline did not collect affiliations of authors from 1966 to 1975, and in addition from 1976 on the collection of affiliations gradually reached and exceeded $95 \%$ only in 1993 , we decided to study affiliations only from 1993 to 2012 . For this period, the total number of articles was 13 687 and the number of affiliations was 13285 . Thus, $97.06 \%$ of the articles had country affiliations that could be determined. Ninety-two countries were identified. The highest absolute production was in the USA, representing $30.91 \%$ of the 13687 articles written (Table IIA). Among the most productive countries, 17 of 25 are classified as developed countries (according to the definition of the United Nations). When normalized by population, Switzerland was the most productive country and the USA was in 7th place (Table IIB). Twenty-two of the top 25 countries were developed countries $(n=22)$. European Nordic countries were efficient when adjustment was made for population. When normalized by GDP, Comoros, Nepal and, Tunisia were the most productive countries and the United States was absent from the top 25 countries (Table IIC). When analyzing continents, Europe was the most productive with 5052 (38.03\%) articles, followed by North America with 4656 (35.05\%) articles and Asia with 2725 (20.51\%) articles (Table III).

\section{DISCUSSION}

International journals represent the most common resource for the methods used in a broader discipline known as bibliometrics. Bibliometrics adopts a quantitative approach to studying all types of documents in order to forecast a discipline's development and to identify and follow trends. From an overall perspective, it has been suggested that no specialty in medicine is any better than its published 12 
literature (17). In our study we used the same methodology of bibliometric analysis that have been already publish $(14,18)$. In ophthalmology, Guerin et al. (8) described an analysis from 2002 to 2006 using only 5 journals. Our study included all journals and demonstrated that bibliometric analysis can provide an interesting view of the development of ocular oncology over a 47-year period. Although the number of articles is not limited in our study, there are limitations: 1) PubMed is the most widely used for bibliometric analysis, but it does not contain all biomedical journals and is biased in favor of English journals $(14,19)$; 2) We were unable to distinguish between basic scientific research and clinical research trials; 3) The methodology for identifying authors' country affiliations did not allow us to assess the country for all articles studied. Furthermore, when present, the country affiliation of the authors indicated only one country per article and fails to identify collaborative research; 4) The address of the corresponding author may not always relate to the country in which the research was conducted. For example, many fellows from outside the United States publish in the United States, then return to their native country. Despite these limitations, this study provides a wide view of scientific productivity related to eye neoplasms.

As the world of scientific literature continues to expand through the 21 st century, the field of ocular oncology also continues to expand. However, the growth of ocular neoplasm publications is lower than for the whole PubMed database, and is linear, which suggests a stabilization of publication rate (20). However, the high number of articles related to eye neoplasms justifies why, in 2015, a journal specifically dedicated to ocular oncology now exist (Ocular oncology and pathology). Articles related to eye neoplasms are published in a vast number of journals $(n=2153)$, which 
is more than the expected theoretical value $(n=811)$. This can be explained by the large spectrum of the subject studied. The core journals identified using Bradford's law showed a high amount of heterogeneity. Thus, we should consider the weight of a journal not only by the number of publications, but also by the peer review process and language of publication as well as the impact factor. The impact factor is the most commonly used indicator for journal importance (21) even though it is widely criticized in the literature (22). However, as shown in this study and others (23), it can fall or even disappear altogether, particularly when a journal changes its name and the old and new titles are not unified (24). A longitudinal study of core journals in occupational health, for example, found that periodicals that change their name often lose their impact factors and also vary in country and language (25). Our study focused on productivity, ie the number of articles published by a journal. Productivity is only a quantity evaluation. In contrast, the IF, which takes into account the average number of citations to articles published by a journal in a two year period, is more qualitative, but does not reflect individual citations of articles. Although PubMed does not permit access to these individual citations of articles, it is often chosen for such studies because of its open access, coverage and international visibility (26).

As expected, English was the predominant language of publication (73.72\%) $(7,14,16,27)$. Similar to findings in other specialties $(2,15,16)$, we reported that the USA is the leading gross contributor. In contrast, using continent analysis, Europe is the largest gross contributor. Of note, the population index and GDP indexes showed that absolute production did not reflect the production per capita and the economic efficiency of countries in the field of eye neoplasms. The production per capita showed a higher proportion of developed countries ( $88 \%$ of the top 25 countries), 
and the production normalized by GDP showed a low proportion of developed countries (32\% of the top 25 countries). These results suggest a lower economic efficiency in developed countries in producing articles related to eye neoplasms. 


\section{REFERENCES}

1. Pritchard A. Statistical bibliography or bibliometrics. J Doc. 1969; 25: 348-9.

2. Grossi F, Belvedere O, Rosso R. Geography of clinical cancer research publications from 1995 to 1999. Eur J Cancer. 2003; 39: 106-11.

3. Glynn RW, Chin JZ, Kerin MJ, Sweeney KJ. Representation of Cancer in the Medical Literature - A Bibliometric Analysis. PLoS One. 2010; 5: e13902.

4. Mandal K, Benson S, Fraser SG. The contribution to ophthalmic literature from different regions of the world. Int Ophthalmol. 2004; 25: 181-4.

5. Ohba N. Bibliometric analysis of the current international ophthalmic publications [Japanese]. Nippon Ganka Gakkai Zasshi. 2005; 109: 115-25.

6. Song X, Tian L, Xie L. Infectious keratitis in China during the past two decades: a bibliometric analysis [Chinese]. Zhonghua Yi Xue Za Zhi. 2011; 91: 1104-7.

7. Xu C-T, Li S-Q, Lü Y-G, Pan B-R. Development of biomedical publications on ametropia research in PubMed from 1845 to 2010: a bibliometric analysis. Int $\mathrm{J}$ Ophthalmol. 2011; 4: 1-7.

8. Guerin MB, Flynn TH, Brady J, O'Brien CJ. Worldwide geographical distribution of ophthalmology publications. Int Ophthalmol. 2009; 29: 511-6.

9. Falagas ME, Pitsouni El, Malietzis GA, Pappas G. Comparison of PubMed, Scopus, Web of Science, and Google Scholar: strengths and weaknesses. FASEB J. 2008; 22: 338-42.

10. DeShazo JP, LaVallie DL, Wolf FM. Publication trends in the medical informatics literature: 20 years of. BMC Med Inf Decis Making. 2009; 9: 7.

11. Goffman W, Warren KS. Dispersion of papers among journals based on a mathematical analysis of two diverse medical literatures. Nature. 1969; 221: $1205-7$.

12. Nash-Stewardddd CE, Kruesi LM, Del Mar CB. Does Bradford's Law of Scattering predict the size of the literature in Cochrane Reviews? J Med Libr Assoc. 2012; 100: 135-8.

13. World Bank Group [Internet]. [cited 2014 Oct 8];Available from: http://www.worldbank.org/

14. Vioque J, Ramos JM, Navarrete-Muñoz EM, García-de-la-Hera M. A bibliometric study of scientific literature on obesity research in PubMed (1988-2007). Obes Rev. 2010; 11: 603-11. 
15. Soteriades E, Falagas M. A bibliometric analysis in the fields of preventive medicine, occupational and environmental medicine, epidemiology, and public health. BMC Public Health. 2006; 6: 301.

16. Robert C, Arreto C-D, Azerad J, Gaudy J-F. Bibliometric overview of the utilization of artificial neural networks in medicine and biology. Scientometrics. 2004; 59: 117-30.

17. Felton JS. Who practices industrial medicine? Results of a survey in Oklahoma. Ind Med Surg. 1957; 26: 525-35.

18. Ramos JM, González-Alcaide G, Bolaños-Pizarro M. Bibliometric analysis of leishmaniasis research in Medline (1945-2010). Parasite Vector. 2013; 6: 55.

19. Ugolini D, Puntoni R, Perera FP, Schulte PA, Bonassi S. A bibliometric analysis of scientific production in cancer molecular epidemiology. Carcinogenesis. 2007; 28: $1774-9$.

20. Fernandez-Cano A, Torralbo M, Vallejo M. Reconsidering Price's model of scientific growth: an overview. Scientometrics. 2004; 61: 301-21.

21. Durieux V, Gevenois PA. Bibliometric Indicators: Quality Measurements of Scientific Publication. Radiology. 2010; 255: 342-51.

22. Brown $\mathrm{H}$. How impact factors changed medical publishing--and science. BMJ. 2007; 334: 561-4.

23. Joseph KS. Quality of impact factors of general medical journals. BMJ. 2003; 326: 283.

24. Linde A. On the pitfalls of journal ranking by Impact Factor. Eur J Oral Sci. 1998; 106: 525-6.

25. Smith DR. Citation analysis and impact factor trends of 5 core journals in occupational medicine, 1985-2006. Arch Environ Occup Health. 2008; 63: 11422.

26. Chou L-F. Medline-based bibliometric analysis of gastroenterology journals between 2001 and 2007. World J Gastroenterol. 2009; 15: 2933-9.

27. Tsay M, Yang Y. Bibliometric analysis of the literature of randomized controlled trials. J Med Libr Assoc. 2005; 93: 450-8. 


\section{FIGURE}

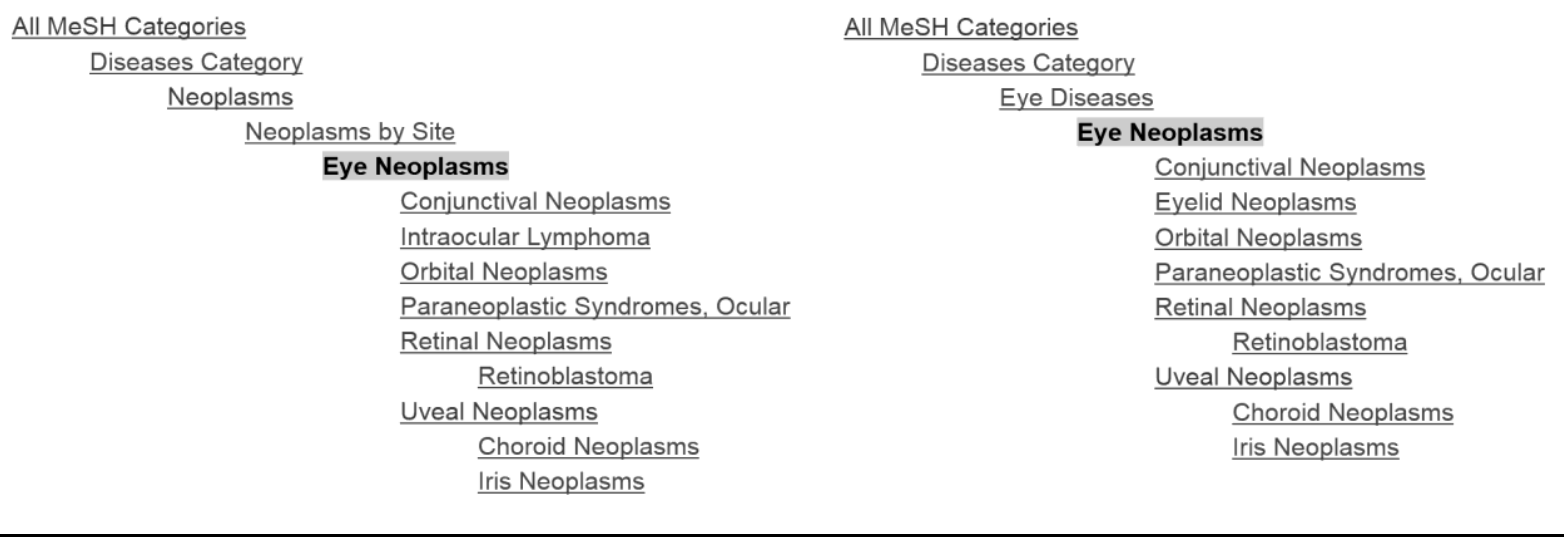

Fig.1 - MeSH trees corresponding to the MeSH term "Eye Neoplasms". This term is located in two different places in the NLM controlled vocabulary thesaurus used for indexing PubMed

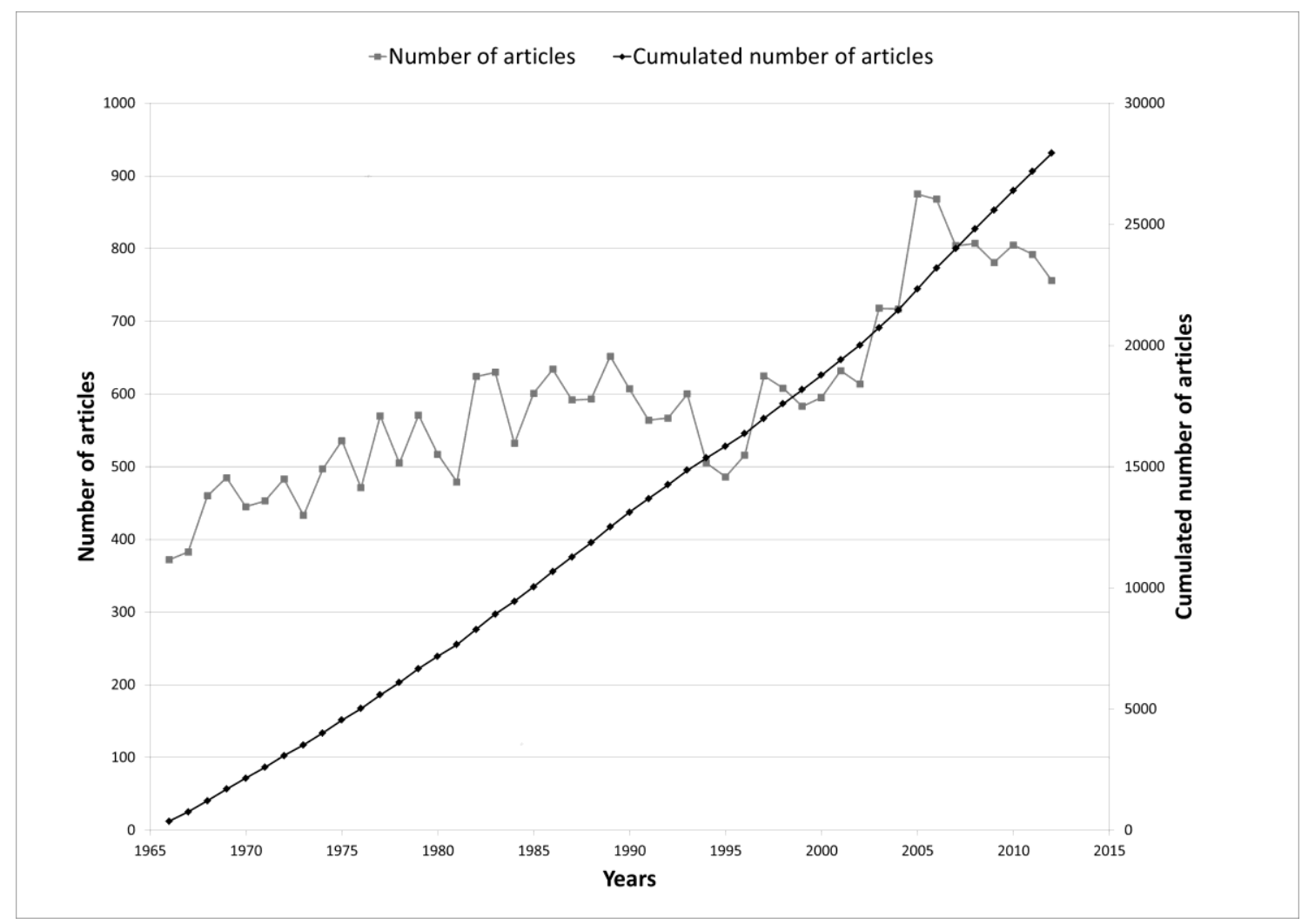


Fig. 2 - Growth of literature related to eye neoplasms (annual number and total number)



Fig. 3 - Total number of articles and number of journals in decreasing order of productivity according to Bradford's law. "Bradford's law states that "If scientific journals are arranged in order of decreasing productivity of articles on a given subject, they may be divided into a nucleus of periodicals more particularly devoted to the subject and several groups or zones containing the same number of articles as the nucleus, when the numbers of periodicals in the nucleus and succeeding zones will be as $1 ; n ; n^{2} . "$. Thus the total number of articles compared to the number of journals in order of decreasing productivity was divided in 3 zones containing the same number of articles 
TABLE IA - Core journals according to Bradford's law (top 17 most productive journals between 1966 and 2012)

\begin{tabular}{|c|c|c|c|c|c|c|c|}
\hline Journal & $\begin{array}{l}\text { Impact Factor }^{\mathrm{a}} \\
\left(\text { JCR rank }{ }^{\mathrm{b}}\right)\end{array}$ & $\begin{array}{l}\text { Language of } \\
\text { publication }\end{array}$ & $\begin{array}{l}\text { Number of } \\
\text { articles related to } \\
\text { eye neoplasms } \\
\text { (Rank) }\end{array}$ & $\begin{array}{l}\text { Articles } \\
\% / \text { total }^{\mathrm{c}}\end{array}$ & $\begin{array}{l}\text { Number of } \\
\text { articles } \\
\text { related to } \\
\text { eye } \\
\text { neoplasms } \\
\text { per year of } \\
\text { activity }\end{array}$ & $\begin{array}{l}\text { Total number } \\
\text { of articles } \\
\text { published by } \\
\text { the journal }\end{array}$ & $\begin{array}{l}\text { Percentage of } \\
\text { articles related } \\
\text { to eye } \\
\text { neoplasms } \\
\text { relative to the } \\
\text { total number of } \\
\text { articles } \\
\text { published }\end{array}$ \\
\hline JAMA Ophthalmology $^{\mathrm{d}}$ & $3.826(3)$ & English & $1260(1)$ & 4.51 & 26.81 & 12263 & 10.27 \\
\hline $\begin{array}{l}\text { American journal of } \\
\text { ophthalmology }\end{array}$ & $3.631(4)$ & English & $1108(2)$ & 3.97 & 23.08 & 14718 & 7.53 \\
\hline Ophthalmology & $5.563(2)$ & English & $910(3)$ & 3.26 & 25.28 & 10223 & 8.90 \\
\hline $\begin{array}{l}\text { The British journal of } \\
\text { ophthalmology }\end{array}$ & $2.725(9)$ & English & $811(4)$ & 2.90 & 16.90 & 10373 & 7.45 \\
\hline $\begin{array}{l}\text { Klinische Monatsblätter } \\
\text { für Augenheilkunde }\end{array}$ & 0.699 (49) & German & $790(5)$ & 2.83 & 16.81 & 9882 & 7.99 \\
\hline $\begin{array}{l}\text { Ophthalmic plastic and } \\
\text { reconstructive surgery }\end{array}$ & $0.671(50)$ & English & $605(6)$ & 2.17 & 21.61 & 2470 & 24.49 \\
\hline $\begin{array}{l}\text { Bulletin des sociétés } \\
\text { d'ophtalmologie de } \\
\text { France * }\end{array}$ & N/A & French & $545(7)$ & 1.95 & 21.8 & 6112 & 8.91 \\
\hline Ophthalmologica & $1.412(35)$ & English & $430(8)$ & 1.54 & 9.15 & 4106 & 10.47 \\
\hline Klinika oczna & $\mathrm{N} / \mathrm{A}$ & Polish & $429(9)$ & 1.54 & 9.33 & 6155 & 6.97 \\
\hline $\begin{array}{l}\text { Journal français } \\
\text { d'ophtalmologie }\end{array}$ & $0.438(53)$ & French & $425(10)$ & 1.52 & 12.14 & 4618 & 9.20 \\
\hline Investigative & $3.441(5)$ & English & 417 (11) & 1.49 & 11.58 & 16033 & 2.60 \\
\hline
\end{tabular}

20 


\begin{tabular}{|l|c|c|c|c|c|c|c|}
\hline $\begin{array}{l}\text { ophthalmology \& visual } \\
\text { science }\end{array}$ & & & & & & \\
\hline Acta Ophthalmologica & 2.345 (15) & English & $306(\mathbf{1 2})$ & 1.10 & 6.51 & 2822 & 10.84 \\
\hline Retina & 2.825 (8) & English & $297(\mathbf{1 3})$ & 1.06 & 9.28 & 4243 & 6.99 \\
\hline $\begin{array}{l}\text { Canadian journal of } \\
\text { ophthalmology }\end{array}$ & 1.145 (39) & English & $279(\mathbf{1 4})$ & 1.00 & 5.94 & 2942 & 9.48 \\
\hline $\begin{array}{l}\text { Annals of } \\
\text { ophthalmology }\end{array}$ & N/A & English & $269(\mathbf{1 5})$ & 0.96 & 11.21 & 3045 & 8.83 \\
\hline Zhonghua yan ke za zhi & N/A & Chinese & $265(\mathbf{1 6})$ & 0.95 & 7.79 & 3894 & 6.80 \\
\hline Vestnik oftalmologii ** & N/A & Russian & $264(\mathbf{1 7})$ & 0.94 & 5.62 & 6165 & 4.28 \\
\hline
\end{tabular}

a IF for year 2012

${ }^{\mathrm{b}}$ Ranking of journals in the Journal Citation Report with IF in the category "Ophthalmology" (Year 2012). This category includes 59 journals

${ }^{c}$ Percentage of articles related to eye neoplasm relative to the total number of articles retrieved in the study $(n=29743)$

${ }^{d}$ Formerly Archives of ophthalmology

* Non peer reviewed. ${ }^{* *}$ Peer review process unknown 
TABLE IB - Core journals according to Bradford's law: number of articles, rank and IF for periods 1966-1972; 1973-1982; 1983-1992; 19932002; 2003-2012

\begin{tabular}{|c|c|c|c|c|c|c|c|c|c|}
\hline \multirow[b]{2}{*}{ Journal } & \multicolumn{9}{|c|}{ Number of articles relative to eye neoplasms (Rank) } \\
\hline & $\begin{array}{l}1966- \\
1972^{a}\end{array}$ & $\begin{array}{l}1973- \\
1982\end{array}$ & $\begin{array}{c}\text { IF } \\
\text { (year } \\
1982 \text { ) }\end{array}$ & $\begin{array}{l}1983- \\
1992\end{array}$ & $\begin{array}{c}\text { IF } \\
\text { (year } \\
1992) \\
\end{array}$ & $\begin{array}{l}1993- \\
2002\end{array}$ &  & $\begin{array}{l}2003- \\
2012\end{array}$ & $\begin{array}{c}\text { IF } \\
\text { (year } \\
2012 \text { ) } \\
\end{array}$ \\
\hline JAMA Ophthalmology $^{\mathrm{b}}$ & $164(2)$ & $267(2)$ & 1.427 & $267(2)$ & 2.007 & $298(1)$ & 2.337 & $264(2)$ & 3.826 \\
\hline American journal of ophthalmology & $215(1)$ & $278(1)$ & 1.331 & $216(3)$ & 2.208 & $225(3)$ & 1.978 & $174(7)$ & 3.631 \\
\hline Ophthalmology & 0 & $127(8)$ & 1.291 & $301(1)$ & 2.142 & $241(2)$ & 2.863 & $241(3)$ & 5.563 \\
\hline $\begin{array}{l}\text { The British journal of } \\
\text { ophthalmology }\end{array}$ & $108(5)$ & $112(9)$ & 0.985 & $194(5)$ & 1.096 & $166(4)$ & 1.779 & $231(4)$ & 2.725 \\
\hline $\begin{array}{l}\text { Klinische Monatsblätter für } \\
\text { Augenheilkunde }\end{array}$ & $141(3)$ & $245(3)$ & 0.262 & $159(6)$ & 0.202 & $131(7)$ & 0.534 & 114 (11) & 0.699 \\
\hline $\begin{array}{l}\text { Ophthalmic plastic and } \\
\text { reconstructive surgery }\end{array}$ & 0 & 0 & N/A & $63(18)$ & 0.204 & $140(5)$ & 0.588 & $402(1)$ & 0.671 \\
\hline $\begin{array}{l}\text { Bulletin des sociétés } \\
\text { d'ophtalmologie de France * }\end{array}$ & $120(4)$ & $217(4)$ & N/A & $208(4)$ & N/A & 0 & $\mathrm{~N} / \mathrm{A}$ & 0 & N/A \\
\hline Ophthalmologica & $90(6)$ & $149(5)$ & 0.333 & $75(11)$ & 0.273 & $68(13)$ & 0.647 & $48(22)$ & 1.412 \\
\hline Klinika oczna & $87(7)$ & $137(7)$ & $\mathrm{N} / \mathrm{A}$ & $69(15)$ & $\mathrm{N} / \mathrm{A}$ & $65(15)$ & $\mathrm{N} / \mathrm{A}$ & $71(18)$ & $\mathrm{N} / \mathrm{A}$ \\
\hline Journal français d'ophtalmologie & 0 & $55(16)$ & N/A & $88(8)$ & 0.057 & $138(6)$ & 0.311 & $144(8)$ & 0.438 \\
\hline $\begin{array}{l}\text { Investigative ophthalmology \& } \\
\text { visual science }\end{array}$ & 0 & $35(21)$ & 2.212 & $76(10)$ & 3.639 & $93(8)$ & 4.091 & $213(5)$ & 3.441 \\
\hline Acta Ophthalmologica & $45(\mathbf{1 0})$ & $52(19)$ & 0.736 & $42(24)$ & 0.413 & $71(12)$ & 0.796 & $96(13)$ & 2,345 \\
\hline Retina & 0 & $10(26)$ & N/A & $64(16)$ & 0.471 & $93(8)$ & 1.058 & $130(9)$ & 2.825 \\
\hline Canadian journal of ophthalmology & 30 (13) & $61(15)$ & 0.422 & $47(22)$ & 0.192 & $46(19)$ & 0.655 & $95(14)$ & 1.145 \\
\hline Annals of ophthalmology & $23(14)$ & $142(6)$ & N/A & $95(7)$ & 0.171 & $9(28)$ & 0.086 & 0 & N/A \\
\hline Zhonghua yan ke za zhi & 0 & $39(20)$ & N/A & $72(12)$ & N/A & $63(16)$ & $\mathrm{N} / \mathrm{A}$ & $91(16)$ & $\mathrm{N} / \mathrm{A}$ \\
\hline Vestnik oftalmologii ** & $51(9)$ & $63(13)$ & N/A & $64(16)$ & 0.062 & $30(24)$ & $\mathrm{N} / \mathrm{A}$ & $56(21)$ & $\mathrm{N} / \mathrm{A}$ \\
\hline
\end{tabular}


* Non peer reviewed. ${ }^{* *}$ Peer review process unknown

$0=$ no paper because the journal was not active

aIF for year 1972 unavailable because IF appears in 1975

${ }^{b}$ Formerly Archives of ophthalmology 
TABLE IC - Other journals (not belonging to the 17 core journals according to Bradford's law) appearing in the top 17 most productive journals for periods 1966-1972; 1973-1982; 1983-1992; 1993-2002; 2003-2012

\begin{tabular}{|c|c|c|c|}
\hline & Journal & $\begin{array}{c}\text { Number of articles related to } \\
\text { eye neoplasms (Rank) }\end{array}$ & $\mathrm{IF}^{\mathrm{a}}$ \\
\hline \multirow{6}{*}{ 1966-1972 } & Oftalmologicheskiĭ zhurnal & $67(8)$ & $\mathrm{N} / \mathrm{A}$ \\
\hline & International ophthalmology clinics & $38(11)$ & $\mathrm{N} / \mathrm{A}$ \\
\hline & Nippon Ganka Gakkai zasshi & $31(\mathbf{1 2})$ & N/A \\
\hline & Survey of ophthalmology & $23(14)$ & $\mathrm{N} / \mathrm{A}$ \\
\hline & Cancer & $22(16)$ & $\mathrm{N} / \mathrm{A}$ \\
\hline & Indian journal of ophthalmology & $8(17)$ & $\mathrm{N} / \mathrm{A}$ \\
\hline \multirow{5}{*}{ 1973-1982 } & Oftalmologicheskiĭ zhurnal & $101(10)$ & $\mathrm{N} / \mathrm{A}$ \\
\hline & Cancer & 83 (11) & 2.657 \\
\hline & Indian journal of ophthalmology & $76(12)$ & N/A \\
\hline & International ophthalmology clinics & $62(14)$ & $\mathrm{N} / \mathrm{A}$ \\
\hline & Ophthalmic surgery & $54(17)$ & 0.541 \\
\hline \multirow{3}{*}{ 1983-1992 } & Ophthalmic surgery & $88(8)$ & 0.607 \\
\hline & Cancer & 70 (13) & 2.271 \\
\hline & Indian journal of ophthalomology & $70(13)$ & $\mathrm{N} / \mathrm{A}$ \\
\hline \multirow{4}{*}{ 1993-2002 } & Der Ophthalmologe & $91(\mathbf{1 0})$ & $\mathrm{N} / \mathrm{A}$ \\
\hline & Graefe's archive for clinical and experimental ophthalmology & $78(11)$ & 1.191 \\
\hline & Journal of pediatric ophthalmology and strabismus & $67(14)$ & 0.434 \\
\hline & Eye & $58(17)$, & 1.028 \\
\hline \multirow{5}{*}{ 2003-2012 } & Orbit & $192(6)$ & $\mathrm{N} / \mathrm{A}$ \\
\hline & Der Ophthalmologe & $125(10)$ & $\mathrm{N} / \mathrm{A}$ \\
\hline & $\begin{array}{c}\text { Graefe's archive for clinical and experimental } \\
\text { Ophthalmology }\end{array}$ & 101 (12) & 1.932 \\
\hline & Eye & $94(15)$ & 1.818 \\
\hline & International journal of radiation oncology, biology, physics & 80 (17) & 4.524 \\
\hline
\end{tabular}


${ }^{a}$ IF for year 1972 unavailable because IF appears in 1975. IF of the year 1982 is given for the period 1973-1982, IF of the year 1992 is given for the period 1983-1992, IF of the year 2002 is given for the period 1993-2002, IF of the year 2012 is given for the period 2003-2012 
TABLE - II: Top 25 countries for publication in ocular oncology (1993-2012). (A) Based on the total number of publications, (B) Based on the number of publications per million inhabitants (population index), (C) Based on the number of publications per 1 billion US dollars of gross domestic product (GDP index)

A

\begin{tabular}{|l|c|} 
A Country & $\begin{array}{c}\text { No. of articles } \\
(\%)\end{array}$ \\
\hline United States & $4231(30.91 \%)$ \\
\hline Germany & $1060(7.74 \%)$ \\
\hline United Kingdom & $839(6.13 \%)$ \\
\hline Japan & $698(5.10 \%)$ \\
\hline China & $623(4.55 \%)$ \\
\hline France & $622(4.54 \%)$ \\
\hline India & $501(3.66 \%)$ \\
\hline Italy & $499(3.65 \%)$ \\
\hline Canada & \\
\hline Spain & $425(3.11 \%)$ \\
\hline Netherlands & $343(2.51 \%)$ \\
\hline Turkey & $314(2.29 \%)$ \\
\hline Australia & $302(2.21 \%)$ \\
\hline Poland & $289(2.11 \%)$ \\
\hline Switzerland & $230(1.68 \%)$ \\
\hline South Korea & $215(1.57 \%)$ \\
\hline Brazil & $196(1.43 \%)$ \\
\hline Israel & $184(1.34 \%)$ \\
\hline Belgium & $150(1.10 \%)$ \\
\hline Romania & $114(0.83 \%)$ \\
\hline Austria & $108(0.79 \%)$ \\
\hline Sweden & $99(0.75 \%)$ \\
\hline Finland & \\
\hline Denmark & \\
\hline Argentina & $(0.72 \%)$ \\
\hline
\end{tabular}

B

\begin{tabular}{|l|c|}
\hline \multicolumn{1}{|c|}{ Country } & $\begin{array}{c}\text { Population } \\
\text { index }\end{array}$ \\
\hline Switzerland & 26.59 \\
\hline Israel & 21.99 \\
\hline Netherlands & 18.16 \\
\hline Finland & 15.70 \\
\hline Denmark & 14.48 \\
\hline Australia & 14.07 \\
\hline $\begin{array}{l}\text { United } \\
\text { States }\end{array}$ & 13.82 \\
\hline $\begin{array}{l}\text { United } \\
\text { Kingdom }\end{array}$ & 13.37 \\
\hline Germany & 12.53 \\
\hline Canada & 12.45 \\
\hline Austria & 11.79 \\
\hline Belgium & 10.72 \\
\hline Sweden & 10.53 \\
\hline Iceland & 10.29 \\
\hline France & 9.60 \\
\hline Singapore & 8.72 \\
\hline Norway & 8.49 \\
\hline Italy & 8.01 \\
\hline Spain & 7.59 \\
\hline Ireland & 6.96 \\
\hline Poland & 5.76 \\
\hline Japan & 5.25 \\
\hline New Zealand & 5.24 \\
\hline Romania & 4.86 \\
\hline Croatia & 4.47 \\
\hline
\end{tabular}

C

\begin{tabular}{|l|l|}
\hline \multicolumn{1}{|c|}{ Country } & GDP index \\
\hline Comoros & 5.72 \\
\hline Nepal & 1.77 \\
\hline Tunisia & 1.29 \\
\hline Romania & 1.22 \\
\hline Uganda & 1.08 \\
\hline Israel & 1.07 \\
\hline Congo, Rep. & 1.04 \\
\hline Malawi & 1.03 \\
\hline Zimbabwe & 1.02 \\
\hline Serbia & 0.88 \\
\hline Poland & 0.80 \\
\hline Turkey & 0.71 \\
\hline Morocco & 0.67 \\
\hline Mali & 0.59 \\
\hline India & 0.55 \\
\hline Croatia & 0.53 \\
\hline Netherlands & 0.52 \\
\hline Switzerland & 0.51 \\
\hline Hungary & 0.51 \\
\hline Finland & 0.47 \\
\hline Nigeria & 0.45 \\
\hline United & 0.43 \\
\hline Kingdom & 0.39 \\
\hline Australia & 0.43 \\
\hline Canada & \\
\hline Germany & \\
\hline
\end{tabular}


TABLE III - Research production of continents in oncology (1993-2012). (A) Based on the total number of publications, (B) Based on the number of publications per million inhabitants (population index), (C) Based on the number of publications per 1 billion US dollars of Gross Domestic Product (GDP index)

\begin{tabular}{|c|c|c|c|c|c|}
\hline A & & B & & $\mathrm{C}$ & \\
\hline Continent & $\begin{array}{c}\text { No. of articles } \\
(\%)\end{array}$ & Continent & $\begin{array}{l}\text { Population } \\
\text { index }\end{array}$ & Continent & GDP index \\
\hline Europe & $5052(38.03 \%)$ & \begin{tabular}{|l|}
$\begin{array}{l}\text { North } \\
\text { america }\end{array}$ \\
\end{tabular} & 13,74 & Oceania & 0,42 \\
\hline North america & $4656(35.05 \%)$ & Oceania & 9,42 & $\begin{array}{l}\text { North } \\
\text { America }\end{array}$ & 0,37 \\
\hline Asia & 2725 (20.51\%) & Europe & 6,58 & Europe & 0,36 \\
\hline Oceania & 312 (2.35\%) & Asia & 0,67 & Africa & 0,24 \\
\hline Latin America* & $309(2.33 \%)$ & \begin{tabular}{|l|} 
Latin \\
America* \\
\end{tabular} & 0,54 & Asia & 0,23 \\
\hline Africa & 231 (1.74\%) & Africa & 0,25 & $\begin{array}{l}\text { Latin } \\
\text { America* }\end{array}$ & 0,10 \\
\hline Total & $13285(100)$ & World & 2,00 & World & 0,3 \\
\hline
\end{tabular}

* and the Caribbean 